1 Differential uplift in the Landquart drainage basin (Prättigau area, eastern Swiss Alps), inferred

2 from landscape shape, sediment fluxes and denudation rates

4 Gabriel Glaus, Romain Delunel, Laura Stutenbecker, Naki Akçar, Marcus Christl, Fritz 5 Schlunegger

\title{
7 Abstract
}

8 There is still a debate about a possible landscape record of the high rock uplift rates measured in 9 the eastern Swiss Alps. This paper focuses on the Landquart drainage basin (Prättigau), where we 10 aim at exploring geomorphic signals related to the differential uplift to the northeast of the city of

11 Chur. We proceed by using concentrations of cosmogenic ${ }^{10} \mathrm{Be}$ to quantify the denudation rates 12 and sediment flux patterns along the Landquart River, which is the trunk stream in the region. 13 Furthermore we use the chemical composition of the fine fraction $(<63 \mu \mathrm{m})$ of the river sediment 14 to determine the provenance of the material, and we quantify the landscape properties through 15 the calculation of steepness and concavitiy values for the tributary basins. The combination of 16 these datasets allows to divide this basin into two parts. In particular, the northeastern upstream 17 segment of the Landquart basin is a glacially imprinted landscape and contributes to about 30-50 $18 \%$ of the total modern sediment flux of the Landquart River. In contrast, the landscape of the 19 downstream southwestern part is dominated by a V-shaped landscape where tributary basins are 20 characterized by high steepness and concavity values. The sediment budgets reveal that this 21 downstream area has delivered about $50-70 \%$ of the total eroded material. Because this 22 lowermost part of the Landquart basin is c. $50 \%$ smaller than the upstream region (c. $200 \mathrm{~km}^{2}$ 23 downstream versus c. $400 \mathrm{~km}^{2}$ upstream), the sediment budget points to very high erosion at 24 work in this lowermost segment. Interestingly, this downstream part is underlain by the 25 easternmost tip of the Aar massif, where young apatite fission track ages suggest the occurrence 26 of ongoing rock uplift, particularly in the Vättis window where the Aar massif is exposed. It 27 appears that the landscape shape and denudation rate pattern in the Landquart basin reflects this 28 ongoing rock uplift, where the updoming of the Aar massif has promoted the streams to respond 29 by fast erosion, $V$-shaped incision and the formation of steep valleys with strongly concave 30 curvatures along the thalweg. 
33 There is a general consensus that the topography of a mountain belt mainly results from the 34 erosional response to the tectonic advection of crustal material (e.g., Willett et al., 2002; Ouimet 35 al., 2009; Champagnac et al., 2012). Erosional processes are different in nature and mainly operate in response to gravitational forces (Strahler, 1952), thereby causing streams to incise into the bedrock and to form relief (Whipple, 2004). However, it has also been reported that erosion and rock uplift are coupled through a positive feedback where enhanced erosional unloading accelerates rock uplift through an isostatic compensation of the eroded material (Whipple, 2009).

40 Such feedback mechanisms between erosion and uplift have been invoked for the Central 41 European Alps (Champagnac et al., 2009; Schlunegger and Hinderer, 2001; Korup and Schlunegger, 42 2009). However, other authors suggested that the present pattern of rock uplift in the Central Alps 43 is more likely related either to neotectonic shortening (Persaud and Pfiffner, 2004) or to isostatic 44 compensations related to the melting of the LGM glaciers and thus to glacial unloading 45 (Gudmundsson, 1994; Barletta et al., 2006; Mey et al., 2016). Although these mechanisms have 46 been well explored in the past years, less research has been conducted on exploring whether the occurrence of differential rock uplift could also be recognized based on the landscape properties and the erosion rate patterns at a drainage basin scale within the Central European Alps. Here, we present evidence for differential rock uplift at work within the Landquart basin, a tributary system of the Rhine headwaters situated in the eastern Alps of Switzerland (Figure 1).

51 We quantify spatially averaged denudation rates using the concentrations of in-situ produced 52 cosmogenic ${ }^{10} \mathrm{Be}$ in alluvial sediments. We complement this dataset with sediment-provenance 53 fingerprinting techniques and investigate the geochemical composition of the eroded materials at different sites within the catchment. Finally, we extract morphometric data from the topography of the tributary catchments, which potentially record the occurrence of differential uplift at work. We combine these methods and resulting datasets in an effort to identify regions of fast rock uplift, possibly characterized by high denudation rates, large sediment fluxes and steep relief, and we will distinguish these from areas where rock uplift rates and thus denudation rates and sediment fluxes are supposedly lower and where the local relief is waned. Such patterns in

60 inferred differential rock uplift will be used to identify possible geodynamic processes occurring at 61 deeper crustal levels.

\section{Local setting}

64 Geomorphology

65 The SE-NW-oriented Landquart basin, situated in the eastern Swiss Alps, is a tributary system 66 within the headwaters of the Rhine River and covers an area of c. $610 \mathrm{~km}^{2}$ (Figure 1). The 67 Landquart River, which is the trunk stream in the basin, originates at $2700 \mathrm{~m}$ a.s.l. and flows into 
the Rhine River at $530 \mathrm{~m}$ a.s.I.. In the headwaters, the Landquart basin hosts four small glaciers. The largest of them is referred to as the Silvretta glacier and is only $3 \mathrm{~km}$ long. Farther downstream from the glaciers, the Landquart basin hosts 11 major tributary systems with various sizes ranging from $7 \mathrm{~km}^{2}$ to c. $30-60 \mathrm{~km}^{2}$ (Figure 1). The five tributary basins in the downstream lower part of the Landquart system (Schranggabach, Taschinasbach, Schraubbach, Buchner Tobel and Furner Bach; Figure 1) are deeply incised, V-shaped basins, while the remaining six tributary basins farther upstream (Ariesch Bach, Schanielabach, Schlappinbach, Stützbach, Verstanclabach and Vernelabach) have U-shaped cross-sectional valley geometries particularly in their headwaters.

During the Quaternary and particularly during the Last Glacial Maximum (LGM) c. 20'000 ka ago, the central Alps including the Landquart basin have been covered by a $\mathrm{km}$-thick ice sheet (Bini et al., 2009), which resulted in the formation of ubiquitous U-shaped landforms with very steep valley flanks (Ivy-Ochs et al. 2008; Montgomery and Korup, 2010). The LGM and previous glaciers in the tributary valleys did not incise as deeply as the main glacier in the trunk channel, with the consequence that hanging valleys with $\mathrm{V}$-shaped inner gorges were formed along the downstream ends of the tributary systems (Korup and Schlunegger, 2007; Valla et al., 2010).

\section{Bedrock geology}

The bedrock of the study area (Figure 1) is made up of a stack of litho-tectonic units dipping towards the southeast (Schmid et al., 1996). In the northwest, the Helvetic nappes are covering the Aar massif (exposed in the Vättis window, Figure 1) and its autochthonous sedimentary cover including the Infrahelvetic nappe stack. During Mesozoic times, these units were deposited on the stretched margin of the European continental plate adjacent to the Valais Ocean in an offshore environment. Farther to the southeast, the Helvetic units are overlain by the Penninic nappe stack, which in turn is divided into three groups according to their palaeogeographic position during Mesozoic times (Schmid et al., 1996). The lower Penninic units are directly covering the Helvetic nappes and consist of the Mesozoic meta-sedimentary fill of the Valais Ocean, where sedimentation occurred in a hemipelagic environment and partly by turbidity currents. The related deposits comprise the Mesozoic Bündnerschists. These deposits, in turn, are overlain by the Cenozoic North-Penninic Flysch (Schmid et al., 1996). The overlying middle Penninic units consist of Mesozoic limestones deposited on a distal spur of the Iberian micro-plate, which has been referred to as the Briançonnais zone in the literature (Schmid et al., 1996). These sediments are found in the Sulzfluh and Falknis thrust sheets and currently mark the northern boundary of the study area (Figure 1). The third and tectonically highest Penninic unit, referred to as the zone of Arosa, had its origin in the Tethys ocean situated to the south of the Briançonnais microcontinent during Mesozoic times, but to the north of the distal margin of the Adriatic microplate. The 
104 Mesozoic phase of spreading resulted in the formation of pillow lavas and ophiolitic rock 105 sequences (Pfiffner, 2010; Trümpy, 1975). The Penninic units are overlain by the Austroalpine 106 sedimentary and crystalline units, which delineated the northern stretched margin of the Adriatic 107 plate during Mesozoic times. They comprise the Tschirpen nappe with Paleozoic crystalline rocks 108 and Mesozoic sediments (Mählmann and Giger, 2012), and the overlying Silvretta nappe with 109 Paleozoic basement units and a Mesozoic suite of limestones farther to the north (Pfiffner, 2010).

110 Seismic surveys have shown that the northeastern spur of the Aar massif underlies the 111 downstream reaches of the Landquart basin (Pfiffner et al., 1997; Figure 1). The Aar massif is a 112 large crystalline unit made up of Variscian basement rocks of the European continental plate, 113 which stretches from the SE to the NW. In addition, this unit has been interpreted as a laterally 114 propagating large-scale fold (e.g. Herwegh et al., 2017; Libourel et al., 2018), where the 115 northeastern tip is situated beneath the Landquart basin (Figure 1). Approximately 4 to 2 Ma-old 116 apatite fission track ages (Wagner and Reimer, 1972), which record the cooling of the host rocks to 117 temperatures between $110-90^{\circ}$ and which have been measured for the Aar massif rocks exposed 118 in the Vättis window (Figure 1), indicate that this unit has experienced the fastest exhumation 119 rates in the Central European Alps during the past millions of years, possibly until the present 120 (Vernon et al., 2008). Persaud and Pfiffner (2004) claimed that this local exhumation pattern, and 121 the related fast rock uplift rates, was caused by neotectonic activities in relation to the eastern 122 extension of the Aar massif. Related effects are also seen by the high surface uplift rates as 123 unraveled by geodetic surveys (Kahle et al., 1997; Schlatter et al., 2005). The effects related to the 124 NE-directed lateral propagation of the Aar massif yielded in the formation of the 'Prättigau half125 window' where deeper Penninic units are exposed (Figure 1), and where the basement thrusts of 126 the Austroalpine units are folded (Weh and Froitzheim, 2001). We thus infer that this uplift might 127 have influenced the topographic evolution of the Landquart basin, which we plan to test in this 128 paper.

\section{Methods}

131 Basin-averaged denudation rates using concentrations of in-situ cosmogenic ${ }^{10} \mathrm{Be}$

132 We estimated catchment-averaged denudation rates using the concentrations of in-situ ${ }^{10} \mathrm{Be}$ in 133 detrital quartz grains of river-born sediments (von Blanckenburg, 2005). To this extent, we 134 collected three stream-sediment samples in the Landquart trunk stream (Lan-1, Lan-5 and Lan-10) 135 and four samples in tributary channels (Lan-2, Lan-11, Lan-12 and Lan-13), as close to the trunk 136 channel as possible (Figure 1). Stream sediment samples were taken where sufficient quartz grains 137 could be identified with hand lenses in the field. Upon sampling, special attention was paid to 138 collect the samples from stream material, transported by fluvial processes only, to avoid 139 perturbations of the ${ }^{10} \mathrm{Be}$ concentrations by local processes, as for example landslides or erosion of 
140 riverbanks. After sampling, the material was processed following the lab protocol reported in 141 Akçar et al. (2012). The samples were sieved to the size-fraction of 0.25-0.5 mm. The non142 magnetic fraction was separated from each sample using a Franz isodynamic magnetic separator. 143 In order to extract only the pure quartz grains, a sequential chemical dissolution was performed. 144 First the non-magnetic fraction was leached with $5 \%$ hydrochloric acid $(\mathrm{HCl})$ to dissolve the 145 carbonates and organic components. All samples were then treated three times with $5 \%$ 146 hydrofluoric acid (HF), followed by three subsequent steps using $2.5 \% \mathrm{HF}$. The etching of the samples with HF resulted in the removal of mineral impurities (e.g. feldspar, oxides and residual carbonates). In addition, it leached out the atmospheric ${ }^{10} \mathrm{Be}$ adsorbed to the quartz grains. The last step of quartz purification was conducted using Aqua Regia in order to dissolve remaining metallic components as well as residual carbonate and organic materials.

151 The chemical separation of ${ }^{10} \mathrm{Be}$ was then performed using the lab protocol of Akçar et al. (2012).

152 First c. $0.2 \mathrm{mg}$ of a $1 \mathrm{~g} / \mathrm{l}$ Be carrier was added to the purified quartz samples, which were then 153 dissolved in concentrated HF. After complete evaporation of the solution, the sample was fumed 154 with $\mathrm{HNO}_{3}$, Aqua Regia and $\mathrm{HCl}$. The separation protocol was then followed by ion155 chromatography columns. Beryllium and iron were then co-precipitated as hydroxides at a pH $\sim 8$. 156 After mixing the $\mathrm{Be} / \mathrm{Fe}$ precipitate with silver nitrate $\left(\mathrm{AgNO}_{3}\right)$ the suspension was dried and baked 157 in a furnace at $675^{\circ} \mathrm{C}$ before the resulting Beryllium oxide (BeO) was finally pressed into copper 158 targets. ${ }^{10} \mathrm{Be} /{ }^{9} \mathrm{Be}$ ratios were measured using the $500 \mathrm{kV}$ TANDY AMS facility at ETH Zurich (Christl 159 et al., 2013) and normalized to ETH in-house standard S2007N (Kubik and Christl, 2010) using the $160{ }^{10}$ Be half-life of $1.387 \pm 0.012 \mathrm{Ma}$ (Korschinek et al., 2010; Chmeleff et al., 2010). The full process 161 blank ratio of $(2.41 \pm 0.13) \times 10^{-15}$ was then subtracted from the measured ratios in order to 162 calculate ${ }^{10} \mathrm{Be}$ concentrations for each sample (Table 1 ).

163 Spatially averaged denudation rates (Table 2) were calculated using the concentrations of in-situ 164 10Be and the CAIRN software (Mudd et al., 2016) in which 10Be production and shielding effects 165 are computed on a pixel-by-pixel basis. Calculations were accomplished using the default 166 parameters in CAIRN, which include a SLHL ${ }^{10} \mathrm{Be}$ production rate of 4.30 at.g-1.a-1, consider the 167 neutrons, fast and slow muons attenuation lengths and contributions following Braucher et al. 168 (2011). A rock density of 2.65 g.cm-3 was used. Snow shielding factors were estimated based on 169 annual snow thickness derived from Auer (2003) and converted to snow water equivalent 170 thickness according to Jonas et al. (2009).

\section{Provenance tracing and mixing modelling}

173 In order to allocate sediment sources and to quantify their relative contributions to the sediment 174 budget of the Landquart basin, we applied a provenance tracing technique. This was conducted 175 based on the chemical composition of the fine fraction $(<63 \mu \mathrm{m})$ of riverine sediments following a 
tributary sampling approach (e.g., Stutenbecker et al., 2018): Sediment was collected from 10 major tributary basins with different bedrock lithologies (Lan-2, 3, 4, 6, 7, 8, 9, 11, 12 and 13) and 3 additional locations within the trunk river (Lan-1, 2 and 10; Figure 1). The $<63 \mu \mathrm{m}$ fraction was extracted through wet-sieving, and the material was dried and sent to the Bureau Veritas Commodities in Vancouver (Canada) for inductively coupled plasma mass spectrometry (ICP-MS) analysis. This yielded concentrations of the main element oxides $\left(\mathrm{SiO}_{2}, \mathrm{Al}_{2} \mathrm{O}_{3}, \mathrm{Fe}_{2} \mathrm{O}_{3}, \mathrm{MgO}, \mathrm{CaO}\right.$, $\mathrm{Na}_{2} \mathrm{O}, \mathrm{K}_{2} \mathrm{O}, \mathrm{TiO}_{2}, \mathrm{P}_{2} \mathrm{O}_{3}, \mathrm{MnO}$ and $\mathrm{Cr}_{2} \mathrm{O}_{3}$ ) as well as of selected trace elements ( $\mathrm{Ba}, \mathrm{Ni}, \mathrm{Sr}, \mathrm{Zr}, \mathrm{Y}, \mathrm{Nb}$ and Sc) (Tables 3 and 4). Compositional end-members were then defined based on principal component analysis techniques (PCA). PCA allows to reduce the data dimensionality and to examine the variance of a dataset (Aitchison 1983, Vermeesch and Garzanti 2015). In order to visualize intra- and inter-sample variability, the compositional data were transformed using the centered-log-ratio-transformation (clr) and plotted in a compositional biplot using the software CoDaPack (Comas and Thió-Henestrosa 2011) (Figure 2). The contributions of each end-member to the three in-stream samples Lan-1, Lan-5 and Lan-10 (pie plots on Figure 3a) were estimated using the mixing modelling R package "fingerPro" developed by Lizaga et al. (2018). Following standard procedures in fingerprinting techniques (e.g. Collins et al., 1996) the data was first statistically verified using (a) the range test to ensure that the in-stream element concentrations were within the range of the sources (mass conservation) and (b) the Kruskal-Wallis-H-test to evaluate the discrimination potential of the elements used. Furthermore, a stepwise discriminant analysis based on the minimization of Wilks' Lambda was performed in order to identify the minimum number of elements providing the largest endmember discrimination (e.g. Collins et al., 2012, Palazón et al., 2015). All tests were performed in $\mathrm{R}$, version 3.5.

Finally, the relative contribution of material from tributary basins to the trunk stream at the sites Lan-1 Lan-5, and Lan-10 were estimated using a simplified end-member mixing model (Figure 3b; see also Savi et al., 2014). To this extent, we assigned relative abundances $x$ and $y(x+y=1)$ to the contribution of material from upstream segments and estimated the compositions $C$ of the sedimentary, ophiolitic and crystalline constituents farther downstream at the sites Lan-1 and Lan-

204 5. For these calculations, we employed the measured concentrations $C_{\text {measured }}$ of the three constituents (sedimentary crystalline, ophiolitic) at the sites Lan-5 and Lan-10. We additionally assigned a relative abundance of $100 \%$ of sedimentary material to the material derived from the

208 Landquart catchment downstream of location Lan-10 is almost entirely composed of sedimentary 209 rocks and flysch units (Figure 1). This then leads to the following end-member mixing equations:

$210 C($ Lan-1 $)=x\left[C_{\text {measured }}(\operatorname{Lan}-5)\right]+\mathrm{y}[C($ trib between Lan-5 and Lan-1) $]$

$211 C(\operatorname{Lan}-1)=\mathrm{x}\left[C_{\text {measured }}(\operatorname{Lan} 10)\right]+\mathrm{y}[C($ trib between Lan-10 and Lan-1) $]$ 
$\left.212 C(\operatorname{Lan}-5)=\mathrm{x}\left[C_{\text {measured }} \operatorname{Lan} 10\right)\right]+\mathrm{y}[C(\operatorname{trib}$ between $\operatorname{Lan}-10$ and Lan-5) $]$

213 We iterated these calculations until the calculated, theoretical concentrations $C(\operatorname{Lan}-1)$ and $C(\operatorname{Lan}-$

214 5) corresponded to the measured ones $C_{\text {measured }}(\operatorname{Lan}-1)$ and $C_{\text {measured }}(\operatorname{Lan}-5)$ at these sites.

Topographic variables

217 For selected tributary basins (Taschinasbach, Schraubbach, Schanielabach, Schlappinbach, and

218 Furner Bach), topographic profiles were extracted along the basin axis from 1:25'000 topographic 219 maps of Swisstopo. We selected these basins because the data on the $\log (S)$ - $\log (A)$ plots (see 220 below) showed clear correlations and trends, which is a prerequisite for a meaningful 221 interpretation. If the data is too noisy on these plots, then identifications of possible controls on 222 the shape of the thalwegs are not possible. The topographic profiles of the aforementioned basins 223 illustrate the lowest and highest points within a segment perpendicular to the basin's axis. The 224 lowest points thus represent the elevation of the thalweg. Accordingly, the elevation difference 225 between the highest and lowest points characterizes the local relief. In addition, for the thalwegs, 226 we calculated the concavity $\theta$ and steepness indices $k_{s}$ using Flint's relationships (Flint, 1974):

$$
S=k_{s} \cdot A^{-\theta}
$$

Here, $S$ is the local slope and $A$ corresponds to the upstream area. We calculated the regression 231 line within a $\log (S)-\log (A)$ plot to quantify the steepness and concavity indices (e.g., Chittenden et 232 al., 2014). An undisturbed river exhibits a concave-up shaped river profile along the entire channel 233 length. However, processes such as rock uplift, glacial sculpting, lithologic contacts, landslide dams 234 and orographic rainfall can disturb the idealized concave shaped river profile (Whipple and Tucker, 235 1999; Korup and Montgomery, 2008; Schlunegger et al., 2011; Walsh et al., 2012). A river is 236 forming a steep segment, referred to as knickzone, along its channel profile upon adjusting to 237 these disturbances. These knickzones then propagate upstream, thereby separating a re-adjusted landscape downstream of the knickzone from an upstream segment that still records the landscape properties prior to the perturbation. In our case, the change form the LGM c. $20^{\prime} 000$

240 years ago to the Holocene represents such a perturbation and conditioned the erosional 241 mechanisms and landscape forms during the Holocene (Salcher et al., 2014). We expect that the 242 erosional processes have adjusted the landscape after glacial retreat through headward erosion, 243 where the knickzones are predicted to have shifted farther upstream and where the related 244 distances most likely depend on the erosion rates. We thus mapped the occurrences of 245 knickzones, and we determined their locations along the thalwegs of the tributary and trunk 246 streams on aerial photographs, in the field and on topographic maps. We finally calculated the 
steepness and concavity indices for the stream segments above and below these knickzones

248 where the data on the $\log (S)-\log (A)$ show clear correlations.

\section{Results}

$251{ }^{10}$ Be derived denudation rates

252 The ${ }^{10} \mathrm{Be}$ concentrations, which we have measured in the seven samples, range from $1.33 \pm 0.12 \mathrm{x}$ $25310^{4}$ atoms. $\mathrm{g}^{-1}$ to $3.97 \pm 0.29 \times 10^{4}$ atoms. $\mathrm{g}^{-1}$ (Table 1 ). The resulting catchment-wide denudation 254 rates vary between $0.33 \pm 0.07 \mathrm{~mm} \cdot \mathrm{y}^{-1}$ (Lan-11) and $1.26 \pm 0.26 \mathrm{~mm} \cdot \mathrm{y}^{-1}$ (Lan-12) (Table 2). They are 255 in the same range as the denudation rates measured in the Eastern Alps (Norton et al., 2010a; 256 Cruz Nunes, 2015) or the Central European Alps (Wittmann et al., 2007; Stutenbecker et al., 2018). 257 The related minimum apparent ages, which correspond to the residence time of rock within the 258 uppermost $60 \mathrm{~cm}$ where most nuclides are produced (e.g. von Blanckenburg, 2006), range 259 between c. 600 and 2300 yrs.

\section{Provenance tracing and mixing modeling}

262 Tables 3 and 4 present the results of the ICP-MS analysis. Table 3 displays the contents of different 263 major element oxides in weight percentage, while Table 4 illustrates the results for the trace 264 elements as well as $\mathrm{Cr}_{2} \mathrm{O}_{3}$ and $\mathrm{MnO}$, which we report in parts per million (ppm) due to their low 265 concentrations.

266 The ICP-MS analysis reveals that all flysch-derived samples (Lan-2, 3, 4, 6, 7, 8, and 9) have much 267 higher contents of $\mathrm{CaO}$ and $\mathrm{Sr}$ than the samples derived from the crystalline and ophiolitic basins. 268 The material encountered in Lan-11, which is derived from an ophiolitic basin, is characterized by its very high content of $\mathrm{Fe}_{2} \mathrm{O}_{3}, \mathrm{MgO}, \mathrm{Cr}_{2} \mathrm{O}_{3}$ and $\mathrm{Ni}$. Lan-12 and 13, both of which are sourced from crystalline basins, show relatively high contents of $\mathrm{SiO}_{2}, \mathrm{Al}_{2} \mathrm{O}_{3}, \mathrm{Na}_{2} \mathrm{O}, \mathrm{MnO}, \mathrm{Sc}, \mathrm{Y}$ and $\mathrm{Nb}$.

271 The ICP-MS results of sample Lan-1, 5 and 10 from the trunk channel can be characterized by two major observations. First, compared to the samples derived from flysch-type lithologies, they have

273 elevated contents of $\mathrm{Na}_{2} \mathrm{O}$ and $\mathrm{Cr}_{2} \mathrm{O}_{3}$, while the concentration of these two oxides decreases 274 between sites Lan-10 and Lan-1. The second observation is the relatively high concentration of

$275 \mathrm{CaO}$ and $\mathrm{Sr}$ compared to the samples derived from basins made up of crystalline and ophiolitic 276 lithologies. Here the related concentrations in the stream sediments increase between sites Lan27710 and Lan-1.

278 The biplot of the ICP-MS analysis in Figure 2 yields three clusters. The first cluster contains the 279 sample Lan-11 sourced in the ophiolitic basin, characterized by high concentrations of $\mathrm{MgO}, \mathrm{Cr}_{2} \mathrm{O}_{3}$, $280 \mathrm{Fe}_{2} \mathrm{O}_{3}$ and $\mathrm{Ni}$. The samples from the flysch basins ( $\operatorname{Lan2}, 3,4,6,7,8$ and 9) generally plot on the left 281 side of the biplot and are dominated by the components $\mathrm{CaO}$ and $\mathrm{Sr}$. There is no detectable 282 compositional difference between sediments derived from Bündnerschist basins (Lan-2, 3 and 4) 
and North Penninic flysch basins (Lan-6, 7, 8 and 9), which is why these basins will be treated as

284 one compositional end-member throughout the following sections. The remaining samples Lan-12

285 and Lan-13 derived from crystalline basins plot in the upper right corner of the biplot. They are 286 defined by the remaining components $\mathrm{Na}_{2} \mathrm{O}, \mathrm{Y}, \mathrm{P}_{2} \mathrm{O}_{5}, \mathrm{MnO}, \mathrm{Sc}, \mathrm{TiO}_{2}$ and $\mathrm{Zr}$.

287 The range test confirmed that all element concentrations in the in-stream samples were within the range of the three source end-members. None of the elements passed the Kruskal-Wallis-H-test, which is probably due to the low number of samples for the ophiolitic $(n=1)$ and the crystalline $(n=2)$ end-member. However, the stepwise selection algorithm suggested a combination of four tracers $\left(\mathrm{Na}_{2} \mathrm{O}, \mathrm{Ni}, \mathrm{Sr}\right.$ and $\left.\mathrm{Sc}\right)$ to provide sufficient end-member discrimination. Sherriff et al. (2015) showed that mixing model accuracy can be improved by maximizing the number of tracers rather than minimizing them through a stepwise selection algorithm. Accordingly, we decided to run the mixing model twice, once with all available elements (run 1) and once with the four selected elements $\mathrm{Na}_{2} \mathrm{O}, \mathrm{Ni}, \mathrm{Sr}$ and $\mathrm{Sc}$ as input tracers (run 2). The relative contributions of the three endmember sources as well as the respective model performance of both runs are displayed in Table 5. The two model runs differ mostly with regard to the ophiolitic contribution, which was calculated to be higher in the first model run. However, we prefer the mixing model solution of the

300 The relative contribution of sediment derived from the three litho-tectonic units are illustrated in 301 the pie charts of Figure 3s for each trunk stream sample location (Lan-1, Lan-5 and Lan-10, results 302 of smodel run 2, Table 5). At site Lan-10, $42 \pm 16 \%$ of the sediment originates from tributaries draining the area composed of crystalline rocks. The basins situated in sedimentary bedrock rock upstream of location Lan-10 deliver $32 \pm 10 \%$ of the material, while the basin made up of ophiolitic lithologies contributes $26 \pm 11 \%$ to the bulk composition of the material at site Lan-10. At location Lan-5, the trunk stream sediment consists of $30 \pm 12 \%$ crystalline, $32 \pm 8 \%$ ophiolitic and $37 \pm 8 \%$ sedimentary material (Figure 3a). Therefore, the ophiolitic constituents remain constant in the relative sense, and the decrease of crystalline material is compensated with a corresponding increase in sedimentary material. At the outlet of the Landquart stream, the relative abundances of crystalline and ophiolitic constituents are significantly lower than at site Lan-5. In particular, at

311 this lowermost site Lan-1, the sediment leaving the Landquart basin consists of $21 \pm 8 \%$ of 312 crystalline, $7 \pm 7 \%$ of ophiolitic and $72 \pm 7 \%$ of sedimentary particles (Figure $3 a$ ).

\section{Sediment budgeting}

315 The three in-stream sample locations Lan-1, 5 and 10 define the three sub-catchments illustrated 316 in the mixing model of Figure 3a. The three pie charts show the relative amount of sediment 317 supplied from the three litho-tectonic units to the in-stream sample locations Lan-1, 5 and 10 . In 318 order to calculate factors for the provenance of sediment from the three sub-catchments, the 
results of the mixing model base on the change of the sediment composition from Lan-10 downstream to Lan-5, and finally to Lan-1 (Figure 3b). Every factor is normalized to its corresponding sub-catchment area (see methods where $x+y=1$ ). At the sample location Lan-1, two cases are possible (Figure $3 \mathrm{~b}$ ). The mixing model suggests that either $40-50 \%$ of the sediment originates from upstream of location Lan-10 and 50-60 \% downstream of location Lan-10, or alternatively 30-50 \% arrives from upstream of location Lan-5 and 50-70\% downstream of location Lan-5. The third case shows that at the sample location Lan-5, 70-90 \% of the sediment originates from upstream of location Lan-10 and 10-30 \% from downstream of location Lan-10. Please note that these budget values are only first-order approximations and base on the silt fraction and hence on the suspension loads of one sample survey only. Accordingly, they have to be treated with caution. Nevertheless, the values yield a distinct picture where a large fraction of the material has been supplied by the tributary basins situated in the downstream segment of the Landquart drainage basin. The relatively high material contribution from this lower region is independently supported by ${ }^{10} \mathrm{Be}$-based sediment budgets measured on in-situ quartz extracted from the sand fraction and thus from the bedload. The corresponding sediment budget is presented in the next section. Annual sediment fluxes were calculated from the mean denudation rates without any error propagation. Hence, they represent estimates only that are shown here as rounded on $10^{\prime} 000$ $\mathrm{m}^{3} \cdot \mathrm{y}^{-1}$ for a better overview (Table 6). The average denudation rate from the entire basin of 1.13 $\mathrm{mm} \mathrm{a}{ }^{-1}$ yields a total sediment flux of $700^{\prime} 000 \mathrm{~m}^{3} \cdot \mathrm{y}^{-1}$. This value can be compared with the actual suspended sediment concentrations measured at the BAFU station Landquart-Felsenbach (Schlunegger and Hinderer, 2003). There, the annual concentration was between 159'000 and 3'450'000 tons between 1994 and 2003 (on average ca. 900'000 tons/year). If the ca. $700^{\prime} 000 \mathrm{~m}^{3}$ derived from the cosmo data is converted into tons (using a density of $2700 \mathrm{~kg} / \mathrm{m}^{3}$ ), then the cosmo-based flux is ca. 1'890'000 tons/year, which is not too far off the measured values, in

344 particular if the usual uncertainties such as grain size, sediment storage and integrating time scales are considered (Hinderer et al., 2014). The cosmo-based flux estimates also reveal that the contribution of the basins upstream of the sample site Lan-10 is approximately $240^{\prime} 000 \mathrm{~m}^{3} \cdot \mathrm{y}^{-1}$. The

347 flux in the trunk stream remains nearly constant, or slightly decreases farther downstream to site 348 Lan-5 $\left(210^{\prime} 000 \mathrm{~m}^{3} \cdot \mathrm{y}^{-1}\right)$. This decrease more likely reflects the large uncertainties (10-30\%) that are 349 associated with this methodology rather than the consequence of in-channel storage of material, 350 for which there is no evidence in the field. Nevertheless, this suggests that a large budgetary 351 contribution of $>400^{\prime} 000 \mathrm{~m}^{3} \cdot \mathrm{y}^{-1}$ has to be inferred for the lowermost tributary basins of the 352 Landquart River, which amounts to c. $70 \%$ of the total sediment flux while it represents $<30 \%$ of 353 the entire basin drainage area. The lowermost tributary basins can thus be considered as the most 354 important erosional hotspot in the region. The second most significant sediment source is situated 
in the catchment upstream of the sampling site Lan-12 in the SE of the Landquart basin. This basin produces approximately $140^{\prime} 000 \mathrm{~m}^{3} \cdot \mathrm{y}^{-1}$ of sediment (Table 6) corresponding to $20-30 \%$ of the total sediment flux.

Topographic variables

360 The shape of river profiles is characterized by the location of a major knickzone, together with the steepness and concavity indices (Figure 4). The knickzones of the Taschinasbach, Schraubbach, and Furner Bach are located in the upper part of the individual catchments, whereas the knickzones of the Schanielabach, the Schlappinbach and Stützback are situated close to the confluence with the trunk channel of the Landquart River. No remarkable knickzones are present in the Schranggabach (Figure 4), which suggests that a possible knickzone might have propagated through the entire drainage basin up to the headwaters. Below the knickzones the steepness and concavity indices reach high values of $>10^{5}$ and $>>0.5$, respectively, while upstream of the knickzones both the steepness and concavity values are significantly smaller.

\section{Discussion}

371 Landscape metrics disclose differences in erosion rates

372 The landscape of the Swiss Alps is still adjusting to the perturbation of the last glaciation, which is 373 expressed by upstream migrating knickzones in the tributary channels but also in the trunk 374 channel. This has been documented at the scale of individual drainage basins (e.g., Chittenden et 375 al., 2014) and at that of the entire Alps (Salcher et al., 2014) through the analysis of steepness and concavity values of streams, and it has also been confirmed through the mapping of knickzones (Norton et al., 2010b). These mechanisms at work can also be observed in the Landquart basin when the locations of the knickzones and the steepness and concavity indices are considered (Figure 4). The sections of the catchments situated above the knickzones are characterized by a flattened topography and U-shaped cross-sectional valley geometries, which is indicative of a glacial landscape (Whipple et al., 1999). Below the knickzones the occurrence of deeply incised channels and $\mathrm{V}$-shaped valley geometries suggests that the streams have rejuvenated the landscapes by fluvial erosion and associated hillslope processes. This interpretation of fluvial adjustment, most likely through fast erosion, is also supported by the pattern of steepness and concavity values that are generally larger in the rejuvenated reaches compared to the river segments above the knickzones (Whipple et al., 1999; Norton et al., 2010b). In addition, Abbühl et al. (2011) have argued that the celerity of knickzone retreat is positively correlated to the rate at

388 which denudation operates within a basin. In this context, the knickzones of the Taschinasbach, 389 Schraubbach and Furner Bach have propagated close to their headwaters, or have already propagated through the entire basin (Schranggabach). This suggests that these basins have 
experienced a pulse of erosion since the termination of the Last Glacial Maximum c. 20'000 years

392 ago. Contrariwise, the knickzones of the basins father to the SE (e.g., Schanielabach, Figure 4) are

393 still situated close to the trunk channel, and some basins are situated even above the knickzone of

394 the trunk stream (e.g., basins upstream of sites Lan-11 and Lan-12). In addition, the shape of these

395 basins, characterized by U-shaped cross-sectional geometries, display features related to glacial 396 sculpting. This suggests these basins have to large extents preserved their original glacial 397 topography, and that erosion in these catchments has been lower in comparison to the basins farther to the NW (downstream of site Lan-5).

\section{Sediment budget of the Landquart basin}

401 The sediment budget of the Landquart basin was established through two different methods.

402 Estimates of the present day sediment fluxes were achieved using the chemical composition of the 403 river sediment along the basin. Furthermore an average annual sediment flux over the past 6004042300 years was calculated based on the inferred ${ }^{10}$ Be-derived denudation rates. In order to 405 compare these data in a quantitative way, the Landquart catchment was divided into three 406 sections, defined by the sample sites Lan-1, Lan-5 and Lan-10. The results (Figure 5) suggest that 407 the total sediment budget of the entire Landquart basin is made up of a $60 \pm 10 \%$ contribution 408 derived from the lowermost segment (green color), while $10 \pm 10 \%$ (yellow color) and $30 \pm 10 \%$ 409 (red color) of the material has been derived from the middle and headwater sections, respectively. 410 We note that the uncertainties on these values are relatively high, but the budget does disclose a 411 distinct trend regarding the provenance of the material. Accordingly, c. 50-70\% of the total 412 sediment from the Landquart basin has been derived from the lowermost part of the catchment, 413 while the relative spatial extent of this region is only one third of the total area of the Landquart 414 basin. This implies that modern denudation rates in this lowermost segment are likely to be much 415 higher compared to the rates inferred for the middle and headwater regions of the basin. This 416 interpretation is supported by the sediment budget that is based on the denudation and sediment 417 flux patterns derived from in-situ ${ }^{10} \mathrm{Be}$. Indeed, these budgets suggest that most of the sediment 418 (up to 70\%) has been delivered from the lowermost part of the Landquart basin, while the 419 contribution of the headwater and middle region is much less (Figure 5). Accordingly, both 420 approaches yield the same patterns where sediment input from the lowermost portion of the 421 Landquart basin has been relatively high. This pattern seems to have existed at least for several 422 hundred years, which corresponds to the integration time scale of the ${ }^{10}$ Be methodology (see 423 above). 
As discussed above, the sediment budget of the Landquart basin suggests the occurrence of an

427 erosional hotspot in the lowermost segment of the catchment where most of the sediment has

428 been derived from (Figure 5). In the same sense, the knickzones of the tributary streams in this

429 segment have propagated close to the headwaters, and the landscape downstream of these

430 knickzones have adapted V-shaped cross-sectional geometries. This is different to the shape of the

431 tributary catchments in the middle and headwater segments of the Landquart basin where

432 sediment supply has been relatively low, and where the original glacial landscape with U-shaped

433 cross-sectional geometries are nearly intact. Also in these basins, the knickzones are still situated

434 close to the confluence with the trunk stream, thus supporting the inferred low denudation rates.

435 Interestingly, the geomorphologically very active lowermost zone lies exactly on top of the eastern

436 extension of the Aar massif at $7 \mathrm{~km}$ depth. Persaud and Pfiffner (2004) claimed that the monitored

437 local high rock-uplift rates (Kahle et al. 1997) and the young rock cooling ages derived from apatite

438 fission track data in the Vättis window (Figure 1; Wagner and Reimer 1972) have to be at least

439 partially connected to the updoming of the eastern extension of the Aar massif. This is consistent

440 with the compilation of apatite fission track ages across the entire Alps by Vernon et al. (2008),

441 who disclose the highest uplift rates in this particular region. Furthermore, Persaud and Pfiffner

442 (2004) show a spatial coincidence between neotectonic faulting and a high seismic activity in the

443 Chur region that also includes the lowermost segment of the Landquart basin. This observation

444 combined with the high differential uplift gradient measured by Kahle et al. (1997) offers the basis

445 to interpret that the Aar massif has been actively updoming in this region, and that the eastern tip

446 of this crystalline massif is still laterally propagating towards the lowermost region of the

447 Landquart basin (Persaud and Pfiffner, 2004). We thus consider that this mechanism is also the

448 driver for the fast erosion in the lowermost region of the Landquart basin, where rock uplift

449 increases the average slope of the local topography. As a result, fluvial erosion and sediment flux

450 are amplified, which could explain the relatively high supply of material derived from this

451 lowermost segment. This updoming of the Aar massif underneath the lowermost segment could

452 also explain why the knickzones have propagated close to the headwaters of the tributary basins

453 overlying this zone of high uplift.

455 The role of bedrock erodibility

456 In the lowermost part of the Landquart basin, the bedrock mainly consists of Bündnerschists and

457 North Penninic Flysch with high bedrock erodibilities (Kühni and Pfiffner, 2001). Here the Penninic

458 units reach the surface in a tectonic window referred to as the 'Prättigau half-window' (Weh and 459 Froitzheim, 2001). Korup and Schlunegger (2009) claimed that mechanically weak bedrock such as 460 the Bündnerschists and North Penninic Flysch may have promoted erosion by fluvial dissection and 461 landsliding. According to their study the accelerated erosion could be explained through a 
mechanism where mechanically weak bedrock may have amplified both erosion and rock uplift

463 through a positive feedback. The sediment budget of this study, however, only partly supports this

464 interpretation. Figures 1 and 4 show that the lowermost section, where the bedrock comprises

465 Bündnerschists and North Penninic Flysch, is characterized by the largest sediment supply and the

466 highest erosion rate. The middle section, however, is also underlain by the mechanically weak

467 North Penninic Flysch, but it contributes to $10 \%$ of the total sediment budget only (Figure 5).

468 Furthermore, the Austroalpine cover nappes with relatively low bedrock erodibilities (Kühni and

469 Pfiffner, 2001) had to be removed before the exhumation of the Bündnerschists and North

470 Penninic Flysch could proceed. Indeed, Weh and Froitzheim (2001) relate the formation of the

471 'Prättigau half-window' to the uplift of a large antiform with an E-W oriented hinge underneath

472 this area. Accordingly, uplift and the formation of this antiform led to the exhumation of the

473 Bündnerschist with a high erodibility (Kühni and Pfiffner, 2001) above its hinge zone, and to the

474 exposure of successively higher tectonic units towards the south and the north. Rock uplift of the

475 Aar massif has also been the most likely driver of fast erosion in the lowermost part of the

476 Landquart basin. Possible positive feedbacks between rock uplift and erosional unloading could

477 have contributed to the amplification of both procesess (Korup and Schlunegger, 2007).

\section{Summary and Conclusion}

480 The sediment budget presented in this study suggests a relationship between the actively 481 updoming eastern extension of the Aar massif and the high denudation rates in the lower 482 Landquart basin. The local topography shows that the southeastern part of the Landquart basin 483 still preserves most of the glacial imprints, while in the northwestern part the landscape, which is 484 underlain by the Aar massif, is in a more mature state with respect to the Holocene climate 485 conditions, dominated by fluvial erosion. The measured denudation pattern and the sediment provenance support the observed trends in the landscape. The main part of the fluvial sediment in the Landquart catchment has been derived from the northwestern part of the basin. Contrariwise, denudation rates determined for the upstream southeastern region are much lower. This pattern

489 is also confirmed by the sediment provenance analysis, pointing to a low sediment input from this 490 part of the Landquart catchment. The sediment budget and the erosional pattern of the Landquart 491 basin therefore appear to be strongly influenced by the actively deforming eastern extension of 492 the Aar massif. Accordingly, this part of the European Alps offers a nice example where differential 493 uplift driven by crustal processes is reflected through distinctively contrasting landscape forms and 494 erosional patterns in the same drainage basin.

\section{Figure captions}


Figure 1: Geological architecture of the Landquart drainage basin. The figure also illustrates the sites where the samples for the provenance analysis and the estimation of 10Be-based

Figure 2: Compositional biplot of the principal component analysis using a centered-log-ratiotransformation. The first two principal components (PC1 and PC2) sum up to $85 \%$.

Figure 3: a) Relative contribution of the three major litho-tectonic units (sedimentary, ophiolitic

Figure 4: Simplified litho-tectonics framework of the Landquart drainage basin, location of

Figure 5: Summary figure, showing the relative contribution of the various segments to the bulk sediment budget of the Landquart basin.

522 Table 1: Cosmogenic nuclide data. Please see Figure 1 for location of sample sites

523 Table 2: ${ }^{10}$ Be derived denudation rates. Please see Figure 1 for location of sample sites

524 Table 3: Content of oxides (\%). Please see Figure 1 for location of sample sites.

525 Table 4: Content of oxides and elements (ppm). Please see Figure 1 for location of sample sites.

526 Table 5: Relative contributions (and uncertainty expressed as the standard deviation) of the

530 Table 6: Sediment budget based on the results of ${ }^{10}$ Be-based denudation rates. Please see Figure 1 for location of sample sites. 
Abbühl, L. M., Norton, K. P., Jansen, J. D., Schlunegger, F., Aldahan, A., \& Possert, G. (2011). Erosion rates and mechanisms of knickzone retreat inferred from ${ }^{10} \mathrm{Be}$ measured across strong climate gradients on the northern and central Andes Western Escarpment. Earth Surface Processes and Landforms, 36, 1464-1473.

Akçar, N., Deline, P., Ivy-Ochs, S., Alfimov, V., Hajdas, I., Kubik, P. W., Christl, M., \& Schlüchter, C. (2012). The AD 1717 rock avalanche deposits in the upper Ferret Valley (Italy): a dating approach with cosmogenic ${ }^{10} \mathrm{Be}$. Journal of Quarternary Science, 27, 383-392.

Aitchison, J. (1983). Principal component analysis of compositional data. Biometrika, 70, 57-65.

Auer, M. (2003). Regionalisierung von Schneeparametern- Eine Methode zur Darstellung von Schneeparametern im Relief. Unpublished Masters Thesis, Universität Bern, Bern, $97 \mathrm{pp}$.

Barletta, V. R., Ferrari, C., Diolauti, G., Carnielli, T., Sabadini, R., \& Smiraglia, C. (2006). Glacier shrinkage and modelled uplift of the Alps: Geophysical Research Letters, 33, L114307, doi:10.1029/2006GL026490.

Bini, A., Buoncristiani, J.-F., Couterrand, S., Ellwanger, D., Felber, M., Florineth, D., Graf, H.R., Keller, O., Kelly, M., Schlüchter, C., \& Schoeneich, P. (2009). Die Schweiz während des letzteiszeitlichen Maximums (LGM) 1:500'000. Bundesamt für Landestopografie Swisstopo, Switzerland.

Braucher, R., Merchel, S., Borgomano, J., \& Bourlès, D.L. (2011). Production of cosmogenic radionuclides at great depth: A multi element approach. Earth and Planetary Science Letters, 309, 1-9.

Champagnac, J.-D., Schlunegger, F., Norton, K., von Blanckenburg, F., Abbühl, L.M., \& Schwab, M., (2009). Erosion-driven uplift of the modern Central Alps. Tectonophysics, 474, 236-249.

Champagnac, J.-D., Molnar, P., Sue, C. \& Herman, F. (2012). Tectonics, climate and mountain belt topography. Journal of Geophysical Research - Solid Earth, 117, B02403.

Chittenden, H., Delunel, R., Schlunegger, F., Akçar, N., \& Kubik, P. (2014). The influence of bedrock orientation on the landscape evolution, surface morphology and denudation (10Be) at the Niesen, Switzerland. Earth Surface Processes and Landforms, 39, 1153-1166.

Chmeleff, J., von Blanckenburg, F., Kossert, K., \& Jacob, D. (2010). Determination of the ${ }^{10}$ Be halflife by multicollector ICP-MS and liquid scintillation counting. Nuclear Instruments and Methods in Physics Research, 268, 192-199.

Christl, M., Vockenhuber, C., Kubik, P.W., Wacker, L., Lachner, J., Alfimov, V., \& Synal, H.A. (2013). The ETH Zurich AMS facilities: performance parameters and reference materials. Nuclear instruments Instruments and Methods in Physics Research, B 294, 29-38.

Collins, A.L., Zhang, Y., McChesney, D., Walling, D.E., Haley, S.M., \& Smith, P. (2012). Sediment source tracing in a lowland agricultural catchment in southern England using a modified procedure combining statistical analysis and numerical modelling. Science of the total Environment, 414, 301-317

Collins, A.L., Walling, D.E., \& Leeks, G.J.L. (1996). Composite fingerprinting of the spatial source of fluvial suspended sediment: a case study of the Exe and Severn river basins, United Kingdom. Géomorphologie: relief, processus, environnement, 2, 41-53

Comas, M., \& Thió-Henestrosa, S. (2011). CoDaPack 2.0: a stand-alone multi-platform compositional software. In J.J. Egozcue, R., Tolosana-Delgado \& M.I. Ortego, M.I. (Eds.), CoDaWork'11: 4th International Workshop on Compositional Data Analysis. Saint Feliu de Guixols, Girona, Spain.

Cruz Nunes, F., Delunel, R., Schlunegger, F., Akçar, N., \& Kubik, P. (2015). Bedrock bedding, landsliding and erosional budgets in the Central European Alps. Terra Nova, 27, 370-378.

Flint, J. J. (1974). Stream Gradient as a Function of Order, Magnitude and Discharge. Water Resources Research, 10, 969-973.

Gudmundsson, G. (1994). An order-of-magnitude estimate of the current uplift-rates in Switzerland caused by the Würm Alpine deglaciation, Eclogae Geologicae Helvetiae, 87, 545-557.

Hinderer, M., Kastowski, M., Kamelger, A., Bartolini, C. \& Schlunegger, F. (2014). River loads and modern denudation of the Alps - a review. Earth-Science Reviews, 118, 11-44. 
Herwegh, M., Berger, A., Baumberger, R., Wehrens, P., \& Kissling, E. (2017). Large-scale crustal-

Ivy-Ochs, S., Kerschner, H., Reuther, A., Preusser, F., Heine, K., Maisch, M., Kubik, P. W., \& Schlüchter, C. (2008). Chronology of the last glacial cycle in the European Alps. Journal of Quaternary Science, 23, 559-573.

Jonas, T., Marty, C., \& Magnusson, J. (2009). Estimating the snow water equivalent from snow depth measurements in the Swiss Alps. Journal of Hydrology, 378, 161-167.

Kahle, H.G., Geiger, A., Bürki, B., Gubler, E., Marti, U., Wirth, B., Rothacher, M., Gurtner, W., Beutler, G., Bauersima, I., \& Pfiffner, O.A. (1997). Recent crustal movements, geoid and density distribution: contribution from integrated satellite and terrestrial measurements. In O.A. Pfiffner, P. Lehner, P. Heitzmann, S. Müller, \& A. Steck, A. (Eds.), Deep structure of the Swiss Alps, results of the National Research Program 20 (NRP 20). Birkhäuser, Basel, pp pp. 251-259.

Korschinek, G., Bergmaier, A., Faestermann, T., Gerstmann, U. C., Knie, K., Maiti, M., Poutivtsev, M. \& Remmert, A., (2010). A new value for the half-life of ${ }^{10}$ Be by heavy-ion elastic recoil detection and liquid scintillation counting. Nuclear Instruments and Methods in Physic Research, B 268, 187-191.

Korup, O., \& Montgomery, D. R. (2008). Tibetan plateau river incision inhibited by glacial stabilization of the Tsangpo gorge. Nature, 445, 786-790.

Korup, O. \& Schlunegger, F. (2009). Rock-type control on erosion-induced uplift, eastern Swiss Alps. Earth and Planetary Science Letters, 278, 278-285.

Kubik, P. W. \& Christl, M. (2010). ${ }^{10} \mathrm{Be}$ and ${ }^{26} \mathrm{Al}$ measurements at the Zurich $6 \mathrm{MV}$ Tandem AMS facility. Nuclear Instruments and Methods in Physics Research, B 268, 880-883.

Kühni, A. \& Pfiffner, O.A. (2001). The relief of the Swiss Alps and adjacent areas and its relation to lithology and structure: topographic analysis from a 250-m DEM. Geomorphology, 41, 285307.

Lizaga, I., Latorre, B., Gaspar, L., \& Navas, A., (2018). fingerPro: An R package for sediment source tracing, https://doi.org/10.5281/zenodo.1402029. Online at https://github.com/eead-csiceesa/fingerPro, last access 17.01.2019

Mählmann, R.F. \& Giger, M. (2012). The Arosa zone in Eastern Switzerland: oceanic, sedimentary burial, accretional and orogenic very low- to low grade patterns in a tectono-metamorphic mélange. Swiss Journal of Geosciences, 105, 203-233.

Mey, J., Scherler, D., Wickert, A.D., Egholm, D.L., Tesauro, M., \& Schildgen, T.F. (2016). Glacial isostatic uplift of the European Alps. Nature Communications, 7, 13382, doi:10.1038/ncomms13382.

Montgomery, D.R., \& Korup, O. (2010). Preservation of inner gorges through repeated Alpine glaciations. Nature Geosciences, 4, 62-67.

Mudd, S.M., Harel, M., Hurst, M.D., Grieve, S.W.D. \& Marrero, S.M. (2016). The CAIRN method: automated, reproducible calculation of catchment-averaged denudation rates from cosmogenic nuclide concentrations. Earth Surface Dynamics, 4, 655-674.

Norton, K.P., von Blanckenburg, F., \& Kubik, P.W. (2010a). Cosmogenic nuclide-derived rates of diffusive and episodic erosion in the glacially sculpted upper Rhone Valley, Swiss Alps. Earth Surface Processes and Landforms, 35, 651-662.

Norton, K.P., Abbühl, L.M., \& Schlunegger, F. (2010b): Glacial conditioning as an erosional driving force in the Central Alps. Geology, 83, 655-658.

Nibourel, L., Berger, A., Egli D., Luensdorf, N.K., \& Herwegh, M. (2018). Large vertical displacements of a crystalline massif recorded by Raman thermometry. Geology, 46, 879882.

Ouimet, W.B., Whipple, K.X., Granger, D.E., (2009). Beyond threshold hill- slopes: Channel adjustment to base-level fall in tectonically active mountain ranges. Geology 37, 579-582.

Palazón, L., Gaspar, L., Latorre, B., Blake, W.H., \& Navas, A. (2015). Identifying sediment sources by applying a fingerprinting mixing model in a Pyrenean drainage catchment. Journal of Soils and Sediments, 15, 2067-2085 
Persaud, M. \& Pfiffner, O. A. (2004). Active deforemation in the eastern Swiss Alps: post-glacial

Pfiffner, O.A. \& Hitz, L. (1997), Geologic interpretation of the seismic profiles of the Eastern Traverse (Llines E1-E3, E7-E9): eastern Swiss Alps. In O.A. Pfiffner, P. Lehner, P. Heitzmann, S. Müller, \& A Steck, A. (Eds.), Deep structure of the Swiss Alps, results of the National Research Program 20 (NRP 20). Birkhäuser, Basel, pp. 73-100

Salcher, B., Kober, F., Kissling, E., \& Willett, S.D. (2014). Glacial impact on short-wavelength topography and long-lasting effects on the denudation of a deglaciated mountain range. Global and Planetary change, 115, 59-70.

Savi, S., Norton, K., Picotti, V., Brardinoni, F., Akçar, N., Kubik, P.W., Delunel, R., \& Schlunegger, F. (2014). Effects of sediment mixing on 10Be concentrations in the Zielbach catchment, central-eastern Italian Alps. Quaternary Geochronology, 19, 148-162.

Schlatter, A., Schneider, D., Geiger, A. \& Kahle, H.G. (2005). Recent vertical movements from precise levelling in the vicinity of the city of Basel, Switzerland. International Journal of Earth Sciences, 94, 507-514.

Schlunegger, F. \& Hinderer, M. (2001). Crustal uplift in the Alps: why the drainage pattern matters. Terra Nova, 13, 425-432.

Schlunegger, F., \& Hinderer, M. (2003). Pleistocene/Holocene climate change, re-establishment of fluvial drainage network and increase in relief in the Swiss Alps. Terra Nova, 15, 88-95.

Schlunegger, F., Norton, K.P., \& Zeilinger, F. (2011), Climate forcing on channel profiles in the Eastern Cordillera of the Coroico region, Bolivia. The Journal of Geology, 119, 97-107.

Schmid, S.M., Pfiffner, O.A., Froitzheim, N., Schönborn, G. \& Kissling, E. (1996). Geophysicalgeological transect and tectonic evolution of the Swiss-Italian Alps. Tectonic,s 15, 10361064.

Sherriff, S.C., Franks, S.W., Rowan, J.S., Fenton, O., \& Ó’hUallacháin, D. (2015). Uncertainty-based assessment of tracer selection, tracer non-conservativeness and multiple solutions in sediment fingerprinting using synthetic and field data. Journal of Soils and Sediments, 15, 2101-2116.

Strahler, A. N. (1952). Hypsometric (area-altitude) analysis of erosional topography. The Geological Society of America Bulletin, 63, 1117-1142.

Stutenbecker, L., Delunel, R., Schlunegger, F., Silva, T.A., Šegvić, B., Girardclos, S., Bakker, M., Costa, A., Lane, S.N., Loizeau, J-L., Molnar, P., Akçar, N., \& Christl, M. (2018), Reduced sediment supply in a fast eroding landscape? A multi-proxy sediment budget of the upper Rhône basin, Central Alps. Sedimentary Geology, 375, 105-119.

Trümpy, R. (1975). Penninic-Austroalpine boundariy in the Swiss Alps: A presumed former continental margin and its problems. American Journal of Science, 275, 209-238.

Valla, P.G., van der Beek, P.A., \& Carcaillet, J. (2010). Dating bedrock gorge incision in the French Western Alps (Ecrins-Pelvoux massif) using cosmogenic ${ }^{10}$ Be. Terra Nova, 22, 18-25.

Vermeesch, P. \& Garzanti, E. (2015). Making geological sense of 'Big Data' in sedimentary provenance analysis. Chemical Geology, 409, 20-27.

Vernon, A. J., van der Beek, P. A., Sinclair, H. D., \& Rahn, M. K. (2008). Increase in late Neogene denudation of the European Alps confirmed by analysis of a fission-track thermochronology database. Earth and Planetary Science Letters, 270, 316-329.

von Blanckenburg, F. (2005). The control mechanisms of erosion and weathering at basin scale from cosmogenic nuclides in river sediment. Earth and Planetary Science Letters, 237, 462479.

Wagner, G. A., \& Reimer, G. M. (1972). Fission track tectonics; the tectonic interpretation of fission track apatite ages. Earth Planetary Science Letter, 14, 263-268.

Walsh, L. S., Martin, A. J., Ojha, T. P., \& Fedenczuk, T. (2012). Correlations of fluvial knickzones with landslide dams, lithologic contacts, and faults in the southwestern Annapurna Range, central Nepalese Himalaya. Journal of Geophysical Research, Vol. 117, doi:10.1029/2011JF001984.

Weh, M., \& Froitzheim, N. (2001). Penninic cover nappes in the Prättigau half-window (Eastern Switzerland): Structure and tectonic evolution. Eclogae Geologicae Helvetiae, 94, 237-252. 
Whipple, K.X., \& Tucker, G.E. (1999). Dynamics of the stream-power river incision model: Implications for height limits of mountain ranges, landscape response timescales, and research needs. Journal of Geophysical Research104, 661-674.

Whipple, K.X., Kirby, E., \& Brocklehurst, S.H. (1999). Geomorphic limits to climate-induced increases in topographic relief. Nature, 401, 39-43.

Whipple, K.X., 2004. Bedrock rivers and the geomorphology of active orogens. Annual Review of Earth and Planetary Sciences, 32, 151-185.

Whipple, K.X. (2009). The influence of climate on the tectonic evolution of mountain belts. Nature Geosciences, 2, 1-8.

Willet, S. D., \& Brandon, M. T. (2002). On steady states in mountain belts. Geology, 30, 175-178.

Wittmann, H., von Blanckenburg, F., Kruesmann, T., Norton, K. P., \& Kubik, P. W. (2007). Relation between rock uplift and denudation from cosmogenic nuclides in river sediment in the Central Alps of Switzerland. Journal of Geophysical Research, 112, doi:10.1029/2006JF000729. 


\section{Lan-13}

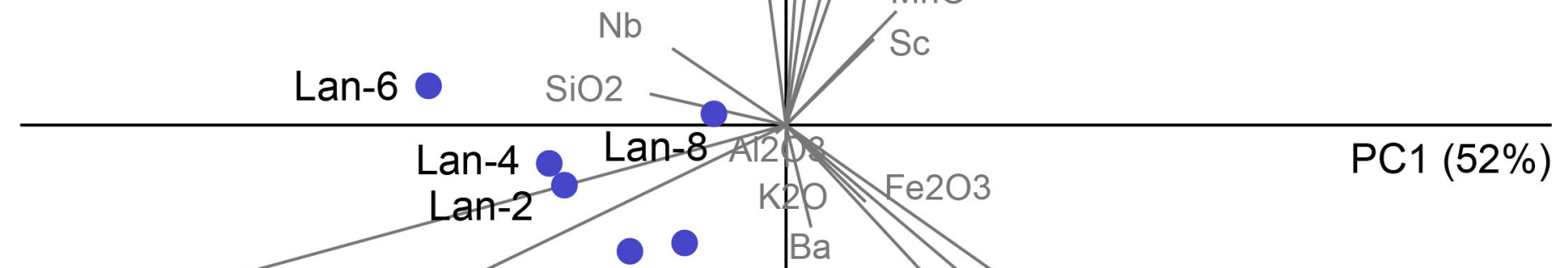

\section{Lan-9 Lan-7} Lan-3 
Provenance of sediment from ICP-MS analysis

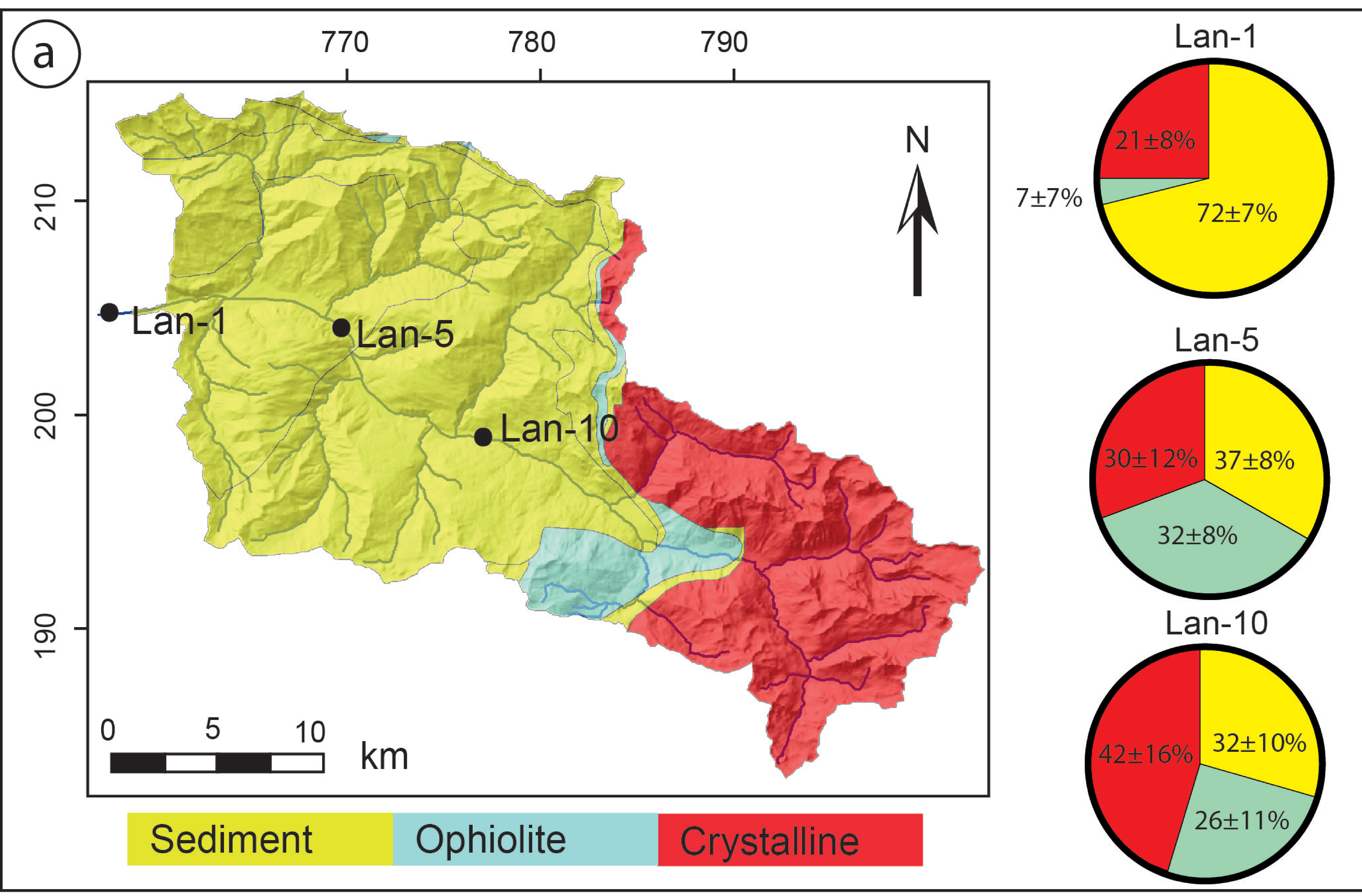

\section{Mixing model} values normalized to area

(b)

Lan-1

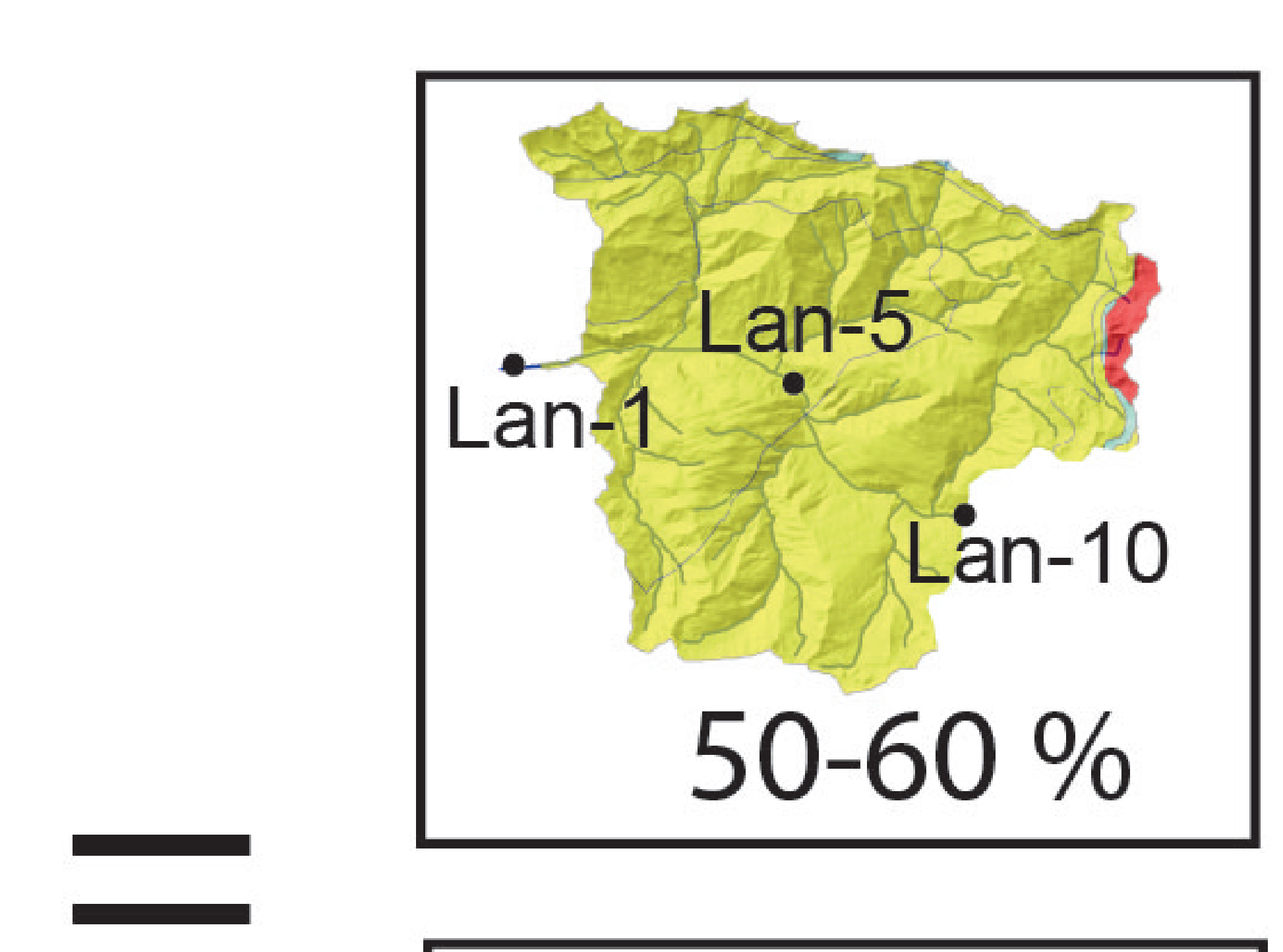

Lan-5
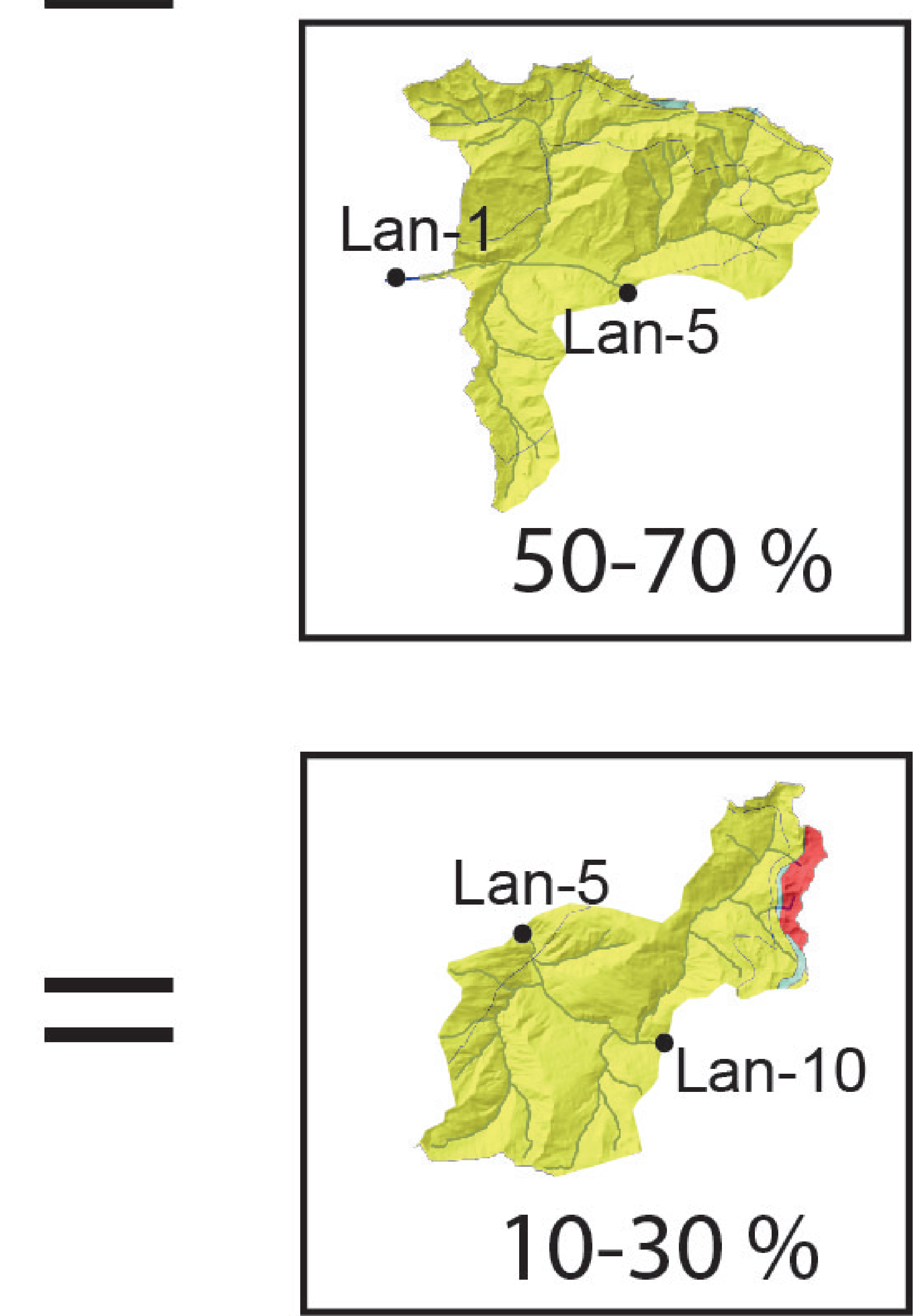

$+$
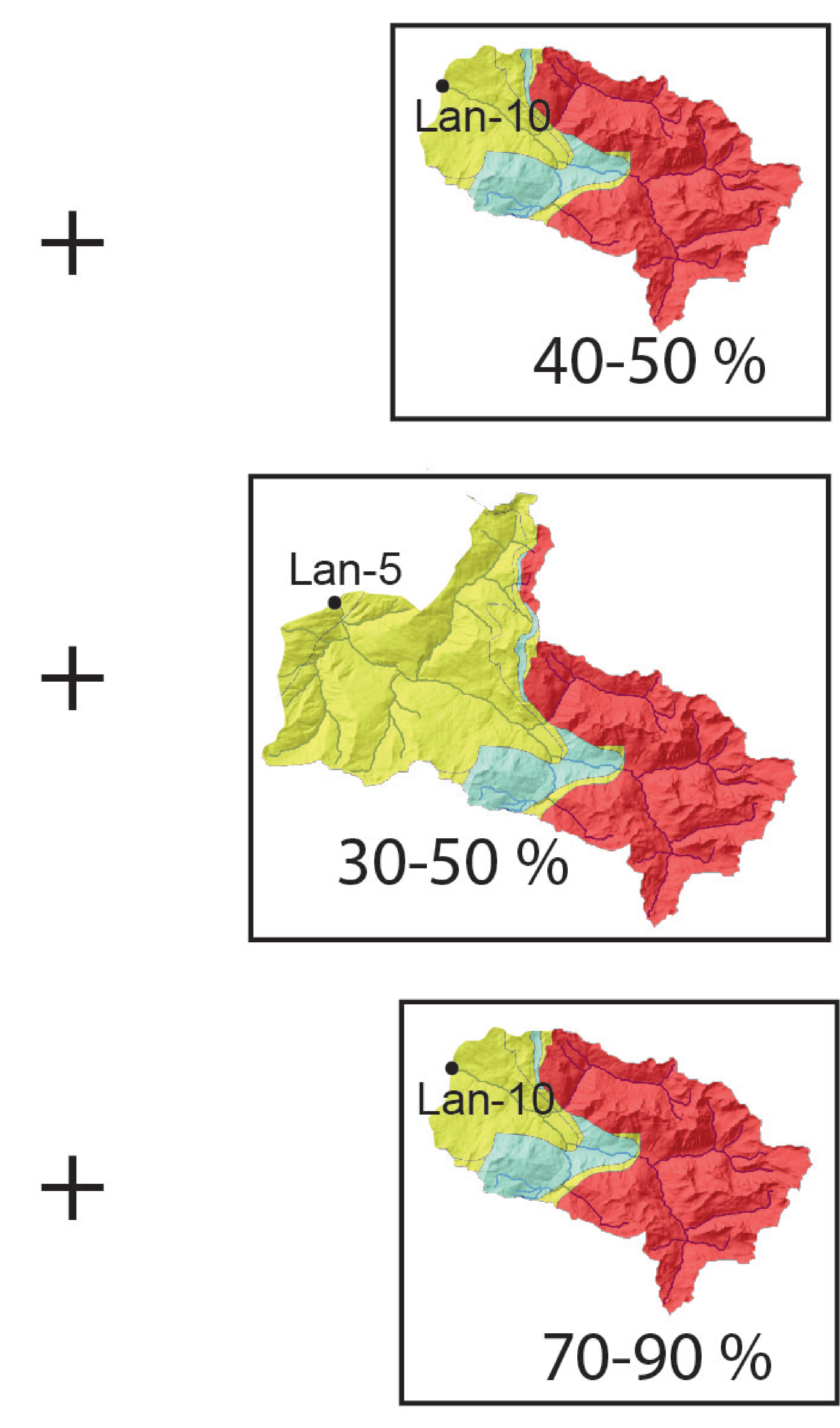

Figure 3 

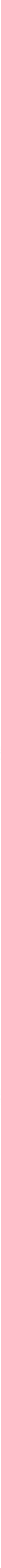

Bünderschist

Flysch
Limestones

Crystalline Basement including Ophilolites
Eastern extension of Aar massif at $7 \mathrm{~km}$ depth 


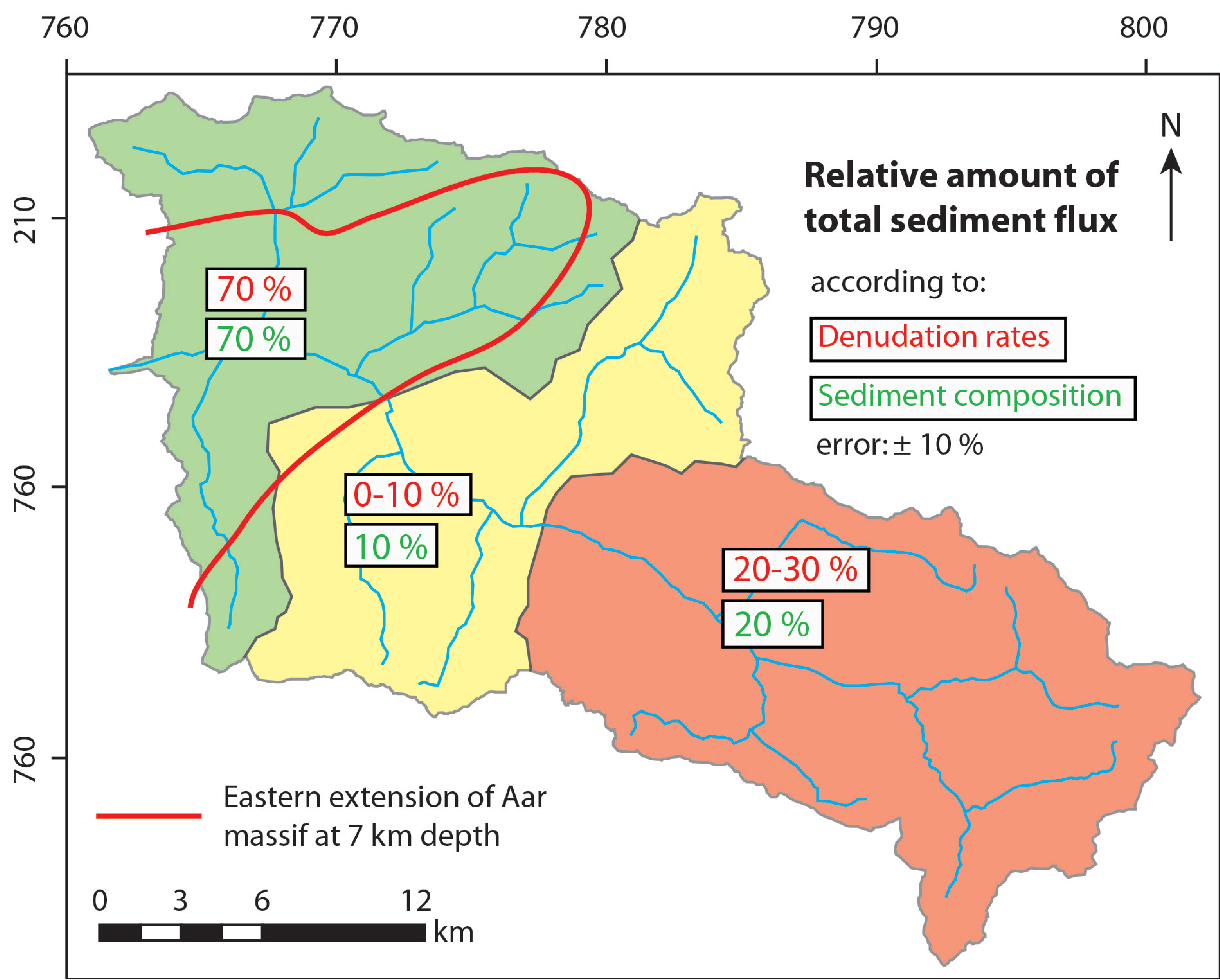

Figure 5 
Table 1

Cosmogenic nuclide data

\begin{tabular}{llllll}
\hline Sample & $\begin{array}{l}\text { Sample } \\
\text { weight } \\
(\mathrm{g})\end{array}$ & $\begin{array}{l}{ }^{9} \mathrm{Be} \\
\text { spike } \\
(\mathrm{mg})\end{array}$ & $\begin{array}{l}\text { AMS } \\
\text { ratio }^{\mathrm{a}} \\
\left(\mathrm{x} \mathrm{10}^{-12}\right)\end{array}$ & $\begin{array}{l}\text { Error in AMS ratio } \\
(\%)\end{array}$ & $\begin{array}{l}\text { 10Be } \\
\text { Concentration } \\
\left(\times 10^{4} \text { atoms } \mathrm{g}^{-1}\right)\end{array}$ \\
\hline Lan-1 & 24.44 & 0.199 & 0.020 & 15.9 & $0.95 \pm 0.17$ \\
Lan-2 & 39.59 & 0.200 & 0.056 & 7.7 & $1.80 \pm 0.15$ \\
Lan-5 & 14.98 & 0.199 & 0.028 & 17.6 & $2.24 \pm 0.43$ \\
Lan-10 & 42.61 & 0.201 & 0.045 & 8.2 & $1.33 \pm 0.12$ \\
Lan-11 & 44.95 & 0.201 & 0.136 & 7.1 & $3.97 \pm 0.29$ \\
Lan-12 & 44.49 & 0.198 & 0.040 & 9.0 & $1.11 \pm 0.11$ \\
Lan-13 & 44.95 & 0.201 & 0.087 & 6.3 & $2.51 \pm 0.16$ \\
\hline
\end{tabular}

Note: The error of AMS ratio is at $1 \sigma$ level. The associated average ${ }^{10} \mathrm{Be} /{ }^{9} \mathrm{Be}$ full process blank ratio is $(2.41 \pm 0.32) \times 10^{-15}$.

\section{Table 2}

${ }^{10} \mathrm{Be}$ derived denudation rates

\begin{tabular}{lllll}
\hline Sample & $\begin{array}{l}\text { Topographic } \\
\text { shielding }\end{array}$ & $\begin{array}{l}\text { Snow } \\
\text { shielding }\end{array}$ & $\begin{array}{l}\text { Denudation rate } \\
\left(\mathrm{mm} \mathrm{a}^{\mathrm{c}}\right)\end{array}$ & $\begin{array}{l}\text { Apparent age }^{\mathrm{d}} \\
\text { (a) }\end{array}$ \\
\hline Lan-1 & 0.957 & 0.882 & $1.13 \pm 0.30$ & 723 \\
Lan-2 & 0.963 & 0.900 & $0.49 \pm 0.10$ & 1538 \\
Lan-5 & 0.957 & 0.875 & $0.51 \pm 0.14$ & 1622 \\
Lan-10 & 0.952 & 0.868 & $0.94 \pm 0.19$ & 800 \\
Lan-11 & 0.968 & 0.866 & $0.33 \pm 0.07$ & 2308 \\
Lan-12 & 0.934 & 0.858 & $1.26 \pm 0.26$ & 600 \\
Lan-13 & 0.957 & 0.865 & $0.52 \pm 0.10$ & 1429 \\
\hline
\end{tabular}

aTopographic shielding factors were calculated after Mudd et al. (2016).

bAnnual snow data from Auer (2003) and empirical relationship derived from Jonas et al. (2009) were used to calculate the snow shielding.

cDenudation rates were calculated using the CAIRN routine (Mudd et al., 2016)

dApparent ages were calculated using an apparent attenuation depth of $60 \mathrm{~cm}$. 
Table 3

Content of oxides (\%)

\begin{tabular}{lllllllllll}
\hline Sample & Lithology & $\mathrm{SiO}_{2}$ & $\mathrm{Al}_{2} \mathrm{O}_{3}$ & $\mathrm{Fe}_{2} \mathrm{O}_{3}$ & $\mathrm{MgO}$ & $\mathrm{CaO}$ & $\mathrm{Na}_{2} \mathrm{O}$ & $\mathrm{K}_{2} \mathrm{O}$ & $\mathrm{TiO}_{2}$ & $\mathrm{P}_{2} \mathrm{O}_{5}$ \\
\hline Lan-1 & & 56.72 & 10.81 & 4.31 & 2.35 & 21.42 & 1.27 & 2.04 & 0.58 & 0.21 \\
Lan-2 & Flysch & 56.38 & 7.29 & 3.02 & 1.78 & 28.86 & 0.55 & 1.33 & 0.38 & 0.16 \\
Lan-3 & Flysch & 43.95 & 11.98 & 4.35 & 7.78 & 28.16 & 0.59 & 2.31 & 0.58 & 0.11 \\
Lan-4 & Flysch & 54.86 & 7.92 & 3.43 & 1.47 & 29.54 & 0.62 & 1.35 & 0.45 & 0.11 \\
Lan-5 & & 56.83 & 12.50 & 5.22 & 6.76 & 13.65 & 1.49 & 2.39 & 0.66 & 0.23 \\
Lan-6 & Flysch & 50.56 & 5.03 & 2.54 & 1.16 & 38.44 & 0.66 & 0.81 & 0.33 & 0.17 \\
Lan-7 & Flysch & 64.11 & 10.58 & 3.48 & 1.56 & 16.76 & 0.59 & 2.12 & 0.51 & 0.10 \\
Lan-8 & Flysch & 58.26 & 10.56 & 5.40 & 1.88 & 20.26 & 0.81 & 1.74 & 0.69 & 0.14 \\
Lan-9 & Flysch & 52.58 & 11.11 & 3.86 & 1.90 & 26.53 & 0.77 & 2.33 & 0.56 & 0.12 \\
Lan-10 & & 60.81 & 12.96 & 4.94 & 5.56 & 10.02 & 1.97 & 2.55 & 0.66 & 0.29 \\
Lan-11 & Ophiolite & 51.68 & 11.48 & 9.02 & 15.89 & 7.46 & 0.98 & 2.16 & 0.63 & 0.22 \\
Lan-12 & Crystalline & 68.56 & 12.28 & 4.26 & 1.82 & 5.14 & 3.15 & 2.00 & 1.39 & 0.89 \\
Lan-13 & Crystalline & 65.13 & 14.69 & 6.22 & 2.86 & 4.26 & 2.90 & 2.82 & 0.72 & 0.19
\end{tabular}

Note: The loss of ignition (LOI) was subtracted for each sample and the concentrations were normalized to $100 \%$.

\section{Table 4}

Content of oxides and elements (ppm)

\begin{tabular}{llllllllll}
\hline Sample & $\mathrm{MnO}$ & $\mathrm{Cr}_{2} \mathrm{O}_{3}$ & $\mathrm{Ba}$ & $\mathrm{Ni}$ & $\mathrm{Sr}$ & $\mathrm{Zr}$ & $\mathrm{Y}$ & $\mathrm{Nb}$ & $\mathrm{Sc}$ \\
\hline Lan-1 & 834 & 167 & 268 & 58 & 848 & 606 & 30 & 15 & 11 \\
Lan-2 & 502 & 75 & 176 & 34 & 1240 & 328 & 20 & 11 & 6 \\
Lan-3 & 659 & 132 & 287 & 42 & 693 & 190 & 17 & 12 & 9 \\
Lan-4 & 756 & 63 & 186 & 25 & 1140 & 258 & 18 & 9 & 8 \\
Lan-5 & 924 & 416 & 296 & 218 & 392 & 367 & 29 & 13 & 13 \\
Lan-6 & 529 & 53 & 110 & 0 & 1838 & 386 & 20 & 8 & 5 \\
Lan-7 & 461 & 92 & 278 & 38 & 768 & 195 & 15 & 8 & 8 \\
Lan-8 & 833 & 119 & 280 & 43 & 789 & 479 & 24 & 12 & 10 \\
Lan-9 & 620 & 112 & 302 & 34 & 1103 & 208 & 17 & 11 & 9 \\
Lan-10 & 889 & 445 & 317 & 178 & 293 & 398 & 34 & 10 & 12 \\
Lan-11 & 1607 & 1492 & 352 & 884 & 126 & 343 & 36 & 10 & 15 \\
Lan-12 & 1925 & 101 & 199 & 28 & 174 & 2538 & 103 & 20 & 19 \\
Lan-13 & 940 & 125 & 437 & 40 & 199 & 180 & 27 & 8 & 15
\end{tabular}

Note: The loss of ignition (LOI) was subtracted for each sample and the concentrations were normalized to $100 \%$. Lithology type of samples see Table 6 . 
Table 5

\begin{tabular}{|c|l|l|l|l|l|}
\hline Model run & $\begin{array}{l}\text { In- } \\
\text { stream } \\
\text { location }\end{array}$ & GOF & $\begin{array}{l}\text { Sedimentary } \\
\text { contribution } \\
(\%)\end{array}$ & $\begin{array}{l}\text { Crystalline } \\
\text { contribution } \\
(\%)\end{array}$ & $\begin{array}{l}\text { Ophiolitic } \\
\text { contribution } \\
(\%)\end{array}$ \\
\hline \multirow{3}{*}{1 (all elements) } & Lan-1 & 80 & $73 \pm 6$ & $6 \pm 7$ & $22 \pm 7$ \\
\cline { 2 - 6 } & Lan-5 & 77 & $45 \pm 6$ & $6 \pm 7$ & $50 \pm 7$ \\
\cline { 2 - 6 } & Lan-10 & 72 & $42 \pm 6$ & $6 \pm 7$ & $51 \pm 7$ \\
\hline \multirow{3}{*}{$2\left(\mathrm{Na}_{2} \mathrm{O}, \mathrm{Ni}, \mathrm{Sr}, \mathrm{Sc}\right)$} & Lan-1 & 93 & $72 \pm 7$ & $21 \pm 8$ & $7 \pm 7$ \\
\cline { 2 - 6 } & Lan-5 & 91 & $37 \pm 8$ & $30 \pm 12$ & $32 \pm 8$ \\
\cline { 2 - 6 } & Lan-10 & 86 & $32 \pm 10$ & $42 \pm 16$ & $26 \pm 11$ \\
\hline
\end{tabular}


Table 6

\begin{tabular}{|c|c|c|c|}
\hline Sample & Area $(\mathrm{km} 2)$ & $\begin{array}{l}\text { Erosion } \\
(\mathrm{mm} / \mathrm{a})\end{array}$ & $\begin{array}{l}\text { Sediment } \\
\text { Flux (m3/a) }\end{array}$ \\
\hline Lan-1 & 616.1 & 1.13 & $700^{\prime} 000$ \\
\hline Lan-2 & 33.9 & 0.49 & $17^{\prime} 000$ \\
\hline Lan-5 & 416.1 & 0.51 & $210^{\prime} 000$ \\
\hline Lan-10 & 252.9 & 0.94 & $240^{\prime} 000$ \\
\hline Lan-11 & 29.1 & 0.33 & $10^{\prime} 000$ \\
\hline Lan-12 & 116.3 & 1.26 & $140^{\prime} 000$ \\
\hline Lan-13 & 45.4 & 0.52 & $24^{\prime} 000$ \\
\hline
\end{tabular}

